\title{
Management of Facilities and Infrastructure in Improving the Quality of Education at SMP Negeri 5 Indralaya Utara
}

\author{
Muslim $^{1 *}$, Happy Fitria², Yenny Puspita ${ }^{2}$ \\ ${ }^{1}$ SMP Negeri 5 Indralaya Utara \\ ${ }^{2}$ Universitas PGRI Palembang \\ *Corresponding author.Email: muslim25252925@gmail.com
}

\begin{abstract}
The article was to determine management Facilities and Infrastructure In Boosting Quality of Education at SMP Negeri 5 North Indralaya. This research uses qualitative methods. The research subjects were the principal, vice principal, teachers and students. Data collection techniques used interviews, observation and documentation. The data were analyzed through reduction, percentage, and conclusion. From the results of data analysis, it can be concluded that the Implementation of Facilities and Infrastructure Management in Improving the Quality of Education at SMP Negeri 5 Indralaya Utara includes Planning Advice and Infrastructure, Organizing Facilities and Infrastructure, Implementing the Management of Facilities and Infrastructure, Controlling Facilities and Infrastructure, Constraints and solutions in implementing management of facilities and infrastructure in improving the quality of education at SMP Negeri 5 Indralaya Utara. The problems in managing facilities and infrastructure at SMP Negeri 5 Indralaya Utara can be seen that: 1) The storage area required funds for expansion and repair. 2) Lack of administrative personnel, especially for the management of facilities and infrastructure. 3) SMP Negeri 5 Indralaya Utara still has a shortage of administrative personnel. b. Solutions for solving budgetary problems by optimizing the limited manpower involved 1) Be more observant in determining the priority scale according to the existing budget. 2) The problem of teaching and education personnel facing the school is by involving existing personnel in courses or education and training officially from the office or outside in order to optimize their performance
\end{abstract}

Keywords: Management Infrastructure, Education Quality, Management Facilities

\section{INTRODUCTION}

Education is the spearhead for the progress of the nation. If the education of a nation is good, then it is good for the next generation, meanwhile, whether or not education in a nation is good or not can be seen from the implementation and orientation of the education system. The more clear the education, the more visible the development and progress of a nation will be. The national education system is an integrated whole component of education to achieve the goals of national education [1]. Education is the most important investment for the nation, especially for a developing nation. Development can only be done by humans who are prepared through education. [2]

To carry out an education in an orderly, orderly and directed manner requires management. Management is the art of doing work through people. Based on the fact that management achieves organizational goals by managing other people.[3] Management or management is an integral component and cannot be separated from the overall educational process, without management it is impossible for educational goals to be realized optimally, effectively, and efficiently.[4] This concept applies in all educational institutions that require effective and efficient management. The purpose of effective and efficient is to be effective and efficient, meaning that the goal is achieved by saving energy, time and costs.

A good educational process certainly requires adequate facilities and infrastructure or facilities, either directly or indirectly. As for the facilities directly related to the educational process such as buildings, study rooms, educational media, tables, chairs and so on. Meanwhile, those that are not directly related are 
the yard, garden, park and road to school. School facilities and infrastructure must meet minimum standards, in this case, it can be seen from [5] article 1 that the standard of facilities and infrastructure for primary schools, junior high schools, and high school includes the minimum criteria for facilities and the minimum criteria for infrastructure.

Educational facilities are tools and equipment that are directly used in the teaching and learning process, such as buildings, classrooms, tables, chairs, and teaching media.[6] Educational infrastructure is facilities that indirectly support the teaching process, such as yards, gardens, school gardens, and roads leading to schools If this infrastructure is used directly for the teaching and learning process such as a school garden to teach biology or a school yard to become a sports field, then this component changes position to become an educational facility. When infrastructure functions as a facility, it means that infrastructure becomes a basic component. However, if the infrastructure is independent or separate, it means that its position is a support for the facilities .

Educational infrastructure is a very important factor in increasing the efficiency of learning and learning. According to Qomar [7] management of educational facilities and infrastructure is defined as the process of collaborating in the utilization of all educational facilities and infrastructure effectively and efficiently. Educational infrastructure is all basic equipment that indirectly supports the implementation of the educational process in schools and educational facilities are all equipment, materials, and furniture that are directly used in the teaching and learning process.[8] Bafadal added that the purpose of infrastructure management is to provide professional services in the field of educational facilities and infrastructure in order to carry out the educational process effectively and efficiently.[9]

Real condition of the existing infrastructure at SMP Negeri 5 Indralaya North this time, SMP Negeri 5 Indralaya North at approximately two years of ago this very concern about the means of infrastructures in order fulfillment and improved quality infrastructure that aims to meet the infrastructure to increase the quality of education at SMP Negeri 5 Indralaya Utara which refers to the [10], regarding the standard of infrastructure as written above, as for the current real conditions of the existing infrastructure in SMP Negeri 5 Indralaya Utara which are loaded with full ratios minimum completeness of infrastructure and facilities.

Based on the inventory data of educational facilities and infrastructure at SMP Negeri 5 Indralaya Utara above, it is known that the existing facilities and infrastructure are quite good, but the problem is that the maintenance and procurement of facilities and infrastructure are not optimal, especially in the maintenance of educational facilities and infrastructure in this school. still not implemented according to standards, as should be done and the utilization has not been fully utilized by all parties who use the educational facilities and infrastructure (Observation of SMP Negeri 5 Indralaya Utara, 2019).

The educational process does require facilities or equipment, but all facilities or equipment must be provided as needed. If the facility is already available, it must be utilized through an optimal process. In the education system, processes are as important as instrumental input and environmental input. Everything will be a determinant in achieving output (out put) and educational outcomes (out come ). In addition, to create quality, of course, many things must be fulfilled besides the infrastructure, but of course there are other components, talking about the quality of education is not as simple as what we say or what we often hear, of course we need to understand what quality is and how. how to make it happen.[11]

So that all facilities can be used optimally in the educational process, these facilities should be managed properly. Management activities include planning, procurement, supervision, storage, inventory, and deletion and arrangement activities. Good management of facilities and infrastructure is expected to create pleasant conditions for both teachers and students to be at school. In addition, it is also hoped that the availability of learning tools or facilities that are adequate quantitatively, qualitatively, and relevant to needs and can be used optimally for the benefit of the education and learning process, both by teachers as teachers, and students as students.[12].

The optimal form of management of facilities and infrastructure is carried out by recruiting certified management personnel, as well as understanding the management of facilities and infrastructure, followed by an inventory of existing facilities and infrastructure as well as the use of facilities and infrastructure. The inventory is also equipped with a user list book for facilities and infrastructure, so that all existing facilities and infrastructure can be controlled in terms of their condition and existence. If there are several facilities and infrastructure that are no longer used, they should be eliminated. [13] SMP Negeri 5 Indralaya Utara is an educational institution that is consistently trying to shape students into knowledgeable, skilled, intelligent people who also have good character. Always foster the belief that wherever he is, Allah SWT is always omniscient in the deeds of His servants. Students are expected to be able to act in accordance with the norms and rules armed with obedience and devotion to Allah.

Etymologically, management comes from English, namely from the verb to manage which means to manage, organize, implement and manage.[14] Management in language means how the process of 
managing, organizing, implementing and managing activities within an agency or organization to achieve goals. Management is the science and art of regulating the process of utilizing human resources and other sources effectively and efficiently to achieve certain goals.[16] Management is an activity to manage, organize, implement and manage a program in an institution so that it can work effectively and efficiently in accordance with objectives.

Management is a series of managerial decisions and actions that determine the company's long-term performance.[17] According to Rohmat [18] management is the art and knowledge to formulate, implement, and evaluate cross-functional decisions that enable an organization to achieve its objectives. Meanwhile, [19] Mulyasa argues that management is a process designed systematically by management to formulate strategies, implement strategies and evaluate strategies in order to provide the best values for all customers to realize the organization's vision.

Educational facilities are tools and equipment that are directly used in the teaching and learning process, such as buildings, classrooms, desks, chairs, and teaching media. Educational infrastructure is facilities that indirectly support the teaching process, such as yards, gardens, school gardens, and roads leading to schools [20] If this infrastructure is used directly for the teaching and learning process such as a school garden to teach biology or a school yard to become a sports field, then this component changes position to become an educational facility. When infrastructure functions as a facility, it means that infrastructure becomes a basic component. However, if the infrastructure stands alone or separately, it means that its position is a support for the facilities. Facility and infrastructure management is an activity that regulates the preparation of all equipment / materials for the implementation of the educational process in schools. Management of facilities and infrastructure is needed to help the teaching and learning process run smoothly.

Quality in education can be seen in terms of its relevance to the needs of society, whether or not a graduate can continue to the next level even to get a good job, as well as a person's ability to overcome life problems.[21] The quality of education can be viewed from the benefit of education for individuals, society and the nation or state.

Specifically, there are those who look at the quality of education in terms of the height and breadth of knowledge that someone who is pursuing education wants to achieve. In the context of education, quality refers to educational processes and outcomes. In the education process, the quality of education is related to teaching materials, methodology, facilities and infrastructure, workforce, financing, environment and so on.[22] However, in terms of educational outcomes, quality is related to the achievements of schools in a certain period of time which can be in the form of academic ability tests, such as general tests, report cards, national examinations, and non-academic achievements such as in sports, arts or skills.

\section{METHODS}

From a methodological perspective, this research is a type of qualitative research. What is meant by qualitative research is a series of activities or the process of capturing information from the normal conditions in the life of an object, connected with a problem, both from a theoretical and practical point of view [15] qualitative approach in my was descriptive. Descriptive research is research on current phenomena. The process carried out is collecting and compiling data, and analyzing and interpreting the data. In essence, qualitative descriptive research is a method of examining the status of a group of humans, an object with the aim of making a systematic, factual and accurate descriptive, image or painting regarding the facts or phenomena being investigated [16]

\section{RESULTS AND DISCUSSION}

Management of educational facilities and infrastructure is a process for procuring and supervising a specific goal in education. If there is no management, the procurement, use, and maintenance of educational facilities and infrastructure will be of little concern to educational institutions. So the phenomenon that will be discussed is how to improve the management of educational facilities and infrastructure which is important to improve the quality of learning in schools. Because of the important role of school facilities and infrastructure for the smooth teaching and learning process, efforts are needed towards the management, procurement, use and maintenance of school facilities and infrastructure as effectively and efficiently as possible [22]

Based on the results of research on the Implementation of Facilities and Infrastructure Management in Improving the Quality of Education at SMP Negeri 5 Indralaya Utara, the results show that: a. Planning Advice and Infrastructure ( Planing )

Planning for facilities and infrastructure at SMP Negeri 5 Indralaya Utara is a step to determine the need for program facilities and infrastructure to be implemented based on the conditions of the facilities and infrastructure owned.

Planning for program facilities and infrastructure through a series of stages, namely coordination meetings, determining school programs, and determining educational facilities and infrastructure needs. After a school coordination meeting is held, the 
next step in planning the facilities and infrastructure is the determination of the school program. Determination of the program at SMP Negeri 5 Indralaya Utara is carried out during a coordination meeting at the beginning of the semester. The determination of the school program is an agreement of all meeting participants for programs to be implemented in the context of improving the quality of education at SMP Negeri 5 Indralaya Utara .

The final step in planning program facilities and infrastructure is determining needs. Determining the need for program facilities and infrastructure at SMP Negeri 5 Indralaya Utara is a step to determine the needs for facilities and infrastructure that support the running of the agreed school program.

Determination of the program facilities and infrastructure needs is carried out at the coordination meeting at the beginning of the semester. The process of determining program facilities and infrastructure needs is based on input from teachers, administrative staff, and mutual agreement at the initial semester meeting.

\section{b. Organizing Facilities and Infrastructure ( Organizing )}

Organizing facilities and infrastructure is an activity to classify the responsibilities of each manager's function in the field of educational facilities and infrastructure. If the organization runs in accordance with the functions and tasks given, the organization in facilities and infrastructure will run smoothly and well. Organizing facilities and infrastructure includes setting up the organizational structure for managing facilities and infrastructure, division of work assignments, arranging tools and practical materials, and setting up practical activities.

The role of the manager in charge of infrastructure are administrative infrastructure, educational facilities plan, plan and manage the needs of tools and materials, proposed the need for tools and materials as educational facilities, reported the condition of facilities and infrastructure to the head of school. The role of head of school is very important and big that guide and motivate subordinates. Support and positive attention given the head of school will greatly assist lab managers in carrying out their duties as possible and they also feel valued at work.

Organizing is a process of preparing an organizational structure and the availability of resources (manpower, finance, infrastructure and facilities) in the organization. There are two important aspects in organizing activities, namely the division of labor and the department. The division of tasks in question is the adjustment of job duties so that each officer in the organization is responsible for carrying out a limited set of activities. The result of the organizing work is the formation of an entity or organizational unit in which there are organizational instruments so that the tasks entrusted to supporters can be carried out.

c. Implementation of Management of Facilities and
Infrastructure (Actuating)
Maintenance of facilities at SMP Negeri 5
Indralaya Utara is the maintenance of school facilities so that they can be used in teaching and learning activities in good condition. Maintenance of school facilities is the responsibility of each person in charge of the work space and in charge of the class. The maintenance of facilities at SMP Negeri 5 Indralaya Utara still requires a warehouse so that unused educational facilities can be safely maintained.

Maintenance is an activity to guard or prevent damage to an item, so that the item is always in good condition and ready to use. Continuous maintenance of all inventory items is sometimes considered a trivial matter, even though this maintenance is a work stage that is no less important ith the other stages in the administration of facilities and infrastructure. Facilities and infrastructure that have been purchased at a high price, if not maintained, cannot be used. Maintenance starts from the user of the item, namely by being careful in using it. Special maintenance must be carried out by professional officers who have expertise in accordance with the type of goods in question.

Procurement is an activity carried out to provide all types of school education facilities and infrastructure in accordance with the needs in order to achieve predetermined goals. In the context of schooling, procurement is all activities carried out by providing all the needs for goods or services based on the results of planning with the aim of supporting learning activities so that they run effectively and efficiently according to the desired goals.

Procurement of facilities and infrastructure is the first operational function in the management of school education facilities and infrastructure. This function is essentially a series of activities to provide school education facilities and infrastructure in accordance with needs, both related to types and specifications, quantity, time and place, with accountable prices and source

Procurement of goods, either carried out by the school or outside the school, should be recorded in accordance with the circumstances and conditions. This is intended as an effort to check and control the entry / exit of school-owned goods or facilities and infrastructure. These notes are written in the format for the provision of educational facilities and infrastructure which are presented in table form as a reference for schools in carrying out activities for the procurement of facilities and infrastructure for schools. 
The elimination of educational facilities and infrastructure at SMP Negeri 5 Indralaya Utara was carried out according to the condition of the objects that were not used so that they did not fill the place. The process of eliminating facilities and infrastructure at SMP Negeri 5 Indralaya Utara through a series of stages, namely the selection of goods, the sale of goods. The elimination of facilities and infrastructure is managed by the school itself. Selection of items for deletion at SMP Negeri 5 Indralaya Utara is the selection of items that are damaged and unused items for deletion. Selection of goods made by those responsible for infrastructure with the approval of the head of the School and treasurer.

To carry out something in an orderly, orderly and directed manner requires management. Management is the art of doing work through people. Based on the fact that management achieves organizational goals by managing other people.[23] Management or management is an integral component and cannot be separated from the overall educational process, without management it is impossible for educational goals to be realized optimally, effectively, and efficiently. This concept applies in all educational institutions or institutions that require effective and efficient management.

\section{d. Control of Facilities and Infrastructure ( Controling )}

Control of facilities and infrastructure at SMP Negeri 5 Indralaya Utara is carried out by taking an inventory of educational facilities and infrastructure. The inventory of educational facilities and infrastructure at SMP Negeri 5 Indralaya Utara will be carried out based on the Directorate General of Quality Improvement of Teachers and Education Personnel of the Ministry of National Education in 2007, regarding the Management of School-Based School Education Facilities and Infrastructure.

The stages currently being carried out are data collection on the facilities and infrastructure owned. The staff for the inventory of facilities and infrastructure, namely the teacher (the facilities and infrastructure section) with the condition of the school who has recently moved buildings and is still in the process of restructuring. SMP Negeri 5 Indralaya Utara has facilities and infrastructure that are physically unique. The arrangement of classrooms and building materials is different from other schools in general

\section{CONCLUSIONS}

The stages currently being carried out are data collection on the facilities and infrastructure owned. The staff for the inventory of facilities and infrastructure, namely the teacher (the facilities and infrastructure section) with the condition of the school who has recently moved buildings and is still in the process of restructuring. SMP Negeri 5 Indralaya Utara has facilities and infrastructure that are physically unique. The arrangement of classrooms and building materials is different from other schools in general.

\section{REFERENCES}

[1] Nasution. (2010). Teknologi Pendidikan. Jakarta: Bumi Aksara.

[2] Wajong, A. D., Ridwan, R., \& Sangi, N. (2020). Efektivitas Penggunaan Pembelajaran Daring Edmodo Berbantuan Quizstar untuk Meningkatkan Hasil Belajar Mahasiswa. Attractive: Innovative Education Journal, 2(3), 49-60.

[3] Fattah, N. (2010). Landasan Manajemen Pendidikan. Bandung: PT Remaja Rosdakarya.

[4] Annur, S., \& Suhono, S. (2019). Implementasi manajemen pergruruan tinggi (studi kasus pada ptkis kopertais wilayah vii sumatera selatan). JMKSP (Jurnal Manajemen, Kepemimpinan, dan Supervisi Pendidikan), 4(1), 67-75.

[5] Peraturan Menteri Pendidikan Nasional No 24 tahun 2007 tentang standar Sarana Prasarana.

[6] Muslimin, E., Fajrussalam, H., Syah, M., \& Erihadiana, M. (2021). The Implementation of Educational Facilities and Infrastructure Management in Supporting Learning Process during Pandemic Covid-19 (Study at SMA Plus As-Salaam Bandung). Bulletin of Science Education, 1(2), 116-123.

[7] Qomar, M. (2017). Manajemen Pendidikan Islam. Malang: Erlangga

[8] Herawati, S., Arafat, Y., \& Puspita, Y. (2020). Manajemen Pemanfaatan Sarana Dan Prasarana Pembelajaran. Attractive: Innovative Education Journal, 2(3), 21-28.

[9] Bafadal, I. (2013). Manajemen Peningkatan Mutu Sekolah Dasar. Bumi Aksara: Jakarta.

[10] Choirul, F. Y. (2018). Budaya Sekolah dan mutu Pendidikan. Jakarta: PT. Pena Citrasatria.

[11] Sugeng. (2017). Implementasi Manajemen Sarana Prasarana Dalam Peningkatan Mutu Pendidikan di MTs Negeri Sragen. IAIN Surakarta

[12] Echols, J. M., \& Shadily, H. (2015). Kamus Inggris Indonesia. Cet. 26, Jakarta: PT. Gramedia.

[13] Hasibuan, M. S. P. (2017). Manajemen Dasar, Pengertian, dan Masalah. Jakarta: Bumi Aksara.

[14] Hunger., \& Wheelen. (2016). Konsep Dasar Manajemen. Jakarta: Rineka Cipta.

[15] Fred. R. (2014). Manajemen Stategis dan Penerapannya dalam Sekolah. Bandung. Alfabeta. 
[16] Asnawan, A. (2021). Enhancement Integrated Quality Management in Islamic Education Institutions. Bulletin of Science Education, 1(1), 42-49.

[17] Hariadi. (2013). Alur Manajemen Strategik. Bandung. Alfabeta.

[18] Rohmat. (2012). Pilar Peningkatan Mut Pendidikan, Yogyakarta: Media Aksara.

[19] E. Mulyasa, (2013). Standar Kompetensi dan Sertifikasi Guru. Bandung: Penerbit Rosdakaya. Rosdakarya

[20] Moleong, L. (2011). Penelitian:Kualitatif. Bandung: Alfabeta.
[21] Rahimah, R., Juriah, N., Karimah, N., Hilmatunnisa, H., \& Sandra, T. (2020). The Problems and Solutions for Learning Activities during Covid-19 Pandemic Disruption in Hidayatul Insan Pondok School. Bulletin of Community Engagement, 1(1), 13-20.

[22] Haryono. (2014). Statistisk Penelitian. Bandung: Alfabeta.

[23] Megasari. (2014). Peningkatan Pengelolaan Sarana dan Prasarana Pendidikan untuk Meningkatan Kualitas Pembelajaran di SMPN 5 Bukittinggi. Skripsi: Tidak Dipublikasikan. 